\title{
KONDISI LINGKUNGAN DI DAERAH YANG PERNAH MENGALAMI KEJADIAN LUAR BIASA JAPANESE ENCEPHALITIS
}

\author{
Nurhidayah, Made Sutarga, Made Pasek Kardiwinata* \\ Program Studi Kesehatan Masyarakat Fakultas Kedokteran Universitas Udayana \\ *Email: pkardiwinata@yahoo.com
}

\begin{abstract}
ABSTRAK
Desa Canggu adalah daerah yang mengalami wabah Japanese encephalitis (JE) pada tahun 2015, dengan kasus klinis JE sebanyak 18 kasus. Penelitian ini bertujuan untuk mengetahui kondisi lingkungan, pencegahan JE di Desa Canggu. Penelitian ini adalah desain cross-sectional deskriptif. Teknik pengambilan sampel menggunakan quota sampling, dari 7 dusun di Desa Canggu diambil masing-masing 22 responden untuk dijadikan sampel dalam penelitian untuk memenuhi sampel kuota minimum yang diperlukan. Sampel penelitian ini adalah responden yang tinggal dalam radius 100 meter dari kandang babi. Jumlah responden dalam wawancara adalah sebanyak 151 orang yang terdiri dari 17 kasus JE dan 134 non JE. Hasil penelitian menunjukkan bahwa 82,84\% responden memiliki lingkungan yang berisiko, sedangkan responden yang tinggal di dekat sawah 14,28\% terinfeksi JE dan responden yang di sekitar lingkungannya terdapat genangan kotor 28,57\% terinfeksi JE. Kesimpulan dari penelitian ini adalah sebagian besar responden memiliki lingkungan yang berisiko. Di mana sebagian besar dari mereka berada dekat dengan lapangan. Disarankan agar pemerintah memberikan pendidikan atau konseling secara adil kepada masyarakat di Desa Canggu, tidak hanya yang pernah mengalami gejala klinis JE tetapi juga masyarakat berisiko tinggi.
\end{abstract}

Kata kunci: Japanese encephalitis, Kondisi Lingkungan, KLB

\begin{abstract}
Canggu Village is an area that has experienced outbreaks of Japanese encephalitis (JE) in 2015 by JE clinical cases as many as 18 cases. This study aims to determine the environmental conditions, of JE prevention in the village of Canggu. This research is a descriptive cross-sectional design. The sampling technique using quota sampling, from 7 hamlets in the village of Canggu taken each 22 respondents to be sampled in the study to meet the minimum required quota sample. The sampling of this research are respondent that live in radius 100 meters from pig stable. The number of respondents in the interview are as many as 151 people consisting of 17 patients and 134 non JE. The results showed that $82.84 \%$ of respondents have a risky environment, whereas respondents that stay near rice terraces $14,28 \%$ get JE and respondent that around their house there is a dirty puddle $28,57 \%$ get JE. The conclusion from this study is most respondents have a risk of environmental conditions. Where the most part of them is stay close to the field. It is recommended that the government to provide education or counseling equitably to community, not only who have experienced clinical symptoms of JE but also high-risk society.
\end{abstract}

Keywords: Japanese encephalitis, Environmental Conditions, Outbreak

\section{PENDAHULUAN}

Penyakit JE merupakan salah satu penyakit yang cukup berbahaya dan menjadi masalah kesehatan masyarakat. Virus Japanese encephalitis (VJE) merupakan penyebab penyakit JE. Penyakit ini bersifat zoonosis akut yang menyebabkan terjadinya radang otak pada manusia serta ditularkan melalui gigitan nyamuk dan akhirnya dapat menyebabkan kematian, cacat fisik, dan cacat mental pada pasiennya (Erlangger et al, 2007). 
Diperkirakan terdapat 50.000 kasus klinis JE dengan CFR sekitar 20\%-30\% (Erlangger et al, 2007). Di Indonesia pada tahun 2005 dilaporkan bahwa terjadi infeksi JE pada berbagai tempat. Berdasarkan hasil surveilans berbasis rumah sakit di enam provinsi di Indonesia tahun 2005-2006 mengatakan bahwa Indonesia merupakan daerah endemis JE dimana persentase positif $\mathrm{Ab}$ JE berkisar antara 1,8\% hingga 17,9\% (Ompusunggu et al, 2008). Berdasarkan data surveilans Dinas Kesehatan Provinsi Bali melaporkan bahwa telah terjadi KLB JE di Desa Canggu dengan jumlah kasus klinis JE sebanyak 18 kasus, dimana 17 diantaranya merupakan warga asli Desa Canggu dan 1 orang merupakan warga negara asing.

Berdasarkan penelitian yang dilakukan di Bali mengatakan bahwa sawah disekitar rumah menunjukkan hasil yang bermakna secara statistik terhadap penyakit JE yaitu dengan RR 69,9 dan p=0,029 (Paramarta, 2009). Dalam penelitian yang dilakukan di Cina mengatakan bahwa faktor risiko lingkungan yang mempengaruhi infeksi JE antara lain adanya daerah persawahan disekitar tempat tinggal $(\mathrm{P}=0,34, \mathrm{p}<0,001)$, adanya kandang babi disekitar tempat tinggal $(\mathrm{P}=0,56)$ dan populasi daerah pedesaan $(\mathrm{P}=0,40)$ (Cao et al, 2010). Adanya tempat istrahat nyamuk seperti semaksemak, kandang ternak, pakaian yang digantung akan berpengaruh terhadap perkembangbiakan nyamuk Culex dengan nilai $p=0,006$ (Ardias, dkk, 2012). Penelitian yang dilakukan di RSUP Sanglah, Bali menunjukkan bahwa terdapat 2 faktor yang berhubungan dengan JE yaitu tempat tinggal dekat sawah $(\mathrm{OR}=5,618, \mathrm{p}=0,000, \mathrm{IK} 95 \%=$ 2,622-12,034) dan memelihara babi $(\mathrm{OR}=$
5,010, p = 0,000, IK95\% = 2,286-10,978) (Putra, $\mathrm{dkk}$, 2007). Beberapa hasil penelitian tersebut mengemukakan bahwa besarnya peran kondisi lingkungan terhadap penyebaran penyakit JE. Oleh karena itu, perlu melihat factor lingkungan terhadap kejadian JE pada daerah yang pernah mengalami KLB JE

\section{METODE}

Penelitian ini adalah penelitian yang mnggunakan rancangan deskriptif crossesctional. Penelitian dilakukan di Desa Canggu selama lima bulan (Januari-Mei) tahun 2016. Desa canggu merupakan desa yang pernah mngalami KLB JE pada bulan November tahun 2015. Pengumpulan data dilakukan dengan menggunakan kuesioner, dimana sampel yang dikumpulkan adalah responden yang berada dalam radius 100 meter dari kandang babi. Data kemudian diolah dengan melihat OR factor lingkungan dengan kejadian JE.

\section{HASIL}

Selama periode penelitian didapatkan 151 responden yang diwawancara, yang terdiri dari 17 orang penderita JE dan 134 non JE. Hasil analisis univariat menunjukkan hasil bahwa Rata-rata umur responden adalah 43 tahun (SD 43,52) dengan kelompok umur terbanyak adalah $\leq 45$ tahun yaitu sebanyak $50,33 \%, 57,62 \%$ responden berjenis kelamin perempuan, $\quad 64,90 \% \quad$ responden berpendidikan tinggi, dan $85 \quad(58,28 \%)$ responden bekerja. Sebagian besar $(83,44 \%)$ responden memiliki kondisi lingkungan yang berisiko terhadap JE. Hasil analisis univariat dan bivariat disajikan dalam Tabel 1-3. 
Tabel 1 Distribusi Frekuensi Umur, Jenis Kelamin, Pendidikan dan Pekerjaan Responden

\begin{tabular}{lcc}
\hline Karakteristik & Frekuensi & Persentase (\%) \\
\hline Kelompok Umur & 76 & 50,33 \\
$\leq 45$ tahun & 75 & 49,67 \\
$>45$ tahun & & \\
\hline Jenis kelamin & 87 & 57,62 \\
Perempuan & 64 & 42,38 \\
Laki-laki & & \\
\hline Pendidikan & 53 & 35,10 \\
Rendah & 98 & 64,90 \\
Tinggi & & \\
\hline Pekerjaan & 63 & 41,72 \\
Tidak bekerja & 88 & 58,28 \\
Bekerja & & \\
\hline
\end{tabular}

Tabel 2. Distribusi Frekuensi Kondisi Lingkungan Responden Terkait Japanese Encephalitis

\begin{tabular}{lcc}
\hline Kondisi lingkungan & Frekuensi & Persentase (\%) \\
\hline Berisiko & 126 & 83,44 \\
Tidak Berisiko & 25 & 16,56 \\
\hline Total & 151 & 100 \\
\hline
\end{tabular}

Tabel 3 Distribusi Frekuensi Berbagai Aspek Kondisi Lingkungan Responden dengan Kejadian Japanese Encephalitis

\begin{tabular}{|c|c|c|c|c|}
\hline \multicolumn{2}{|c|}{ Pertanyaan Kondisi Lingkungan } & \multicolumn{2}{|c|}{ Kejadian JE } & \multirow[t]{2}{*}{ OR } \\
\hline & & Ya & Tidak & \\
\hline \multirow{2}{*}{ 1. Tempat tinggal dekat } & $\mathrm{Ya}$ & $15(14,28)$ & $105(85,72)$ & 2 \\
\hline & Tidak & $2(6,9)$ & $29(93,1)$ & \\
\hline \multirow{2}{*}{$\begin{array}{l}\text { 2. Terdapat genangan air } \\
\text { kotor disekitar rumah }\end{array}$} & $\mathrm{Ya}$ & $2(28,57)$ & $7(72,43)$ & 2,4 \\
\hline & Tidak & $15(11,81)$ & $127(88,19)$ & \\
\hline
\end{tabular}


Hasil analisis menunjukkan bahwa yang bertempat tinggal dekat dengan sawah dan menderita sakit JE sebesar $14,28 \%$, dan $85,72 \%$ tidak menderita penyakit JE, sedangkan yang tidak tinggal dekat sawah hanya $6,9 \%$ menderita sakit JE. Nilai odd ratio (OR) untuk tempat tinggal dekat sawah dengan kejadiaan JE adalah 2. Artinya, tempat tinggal dekat sawah dengan kejadian JE kemungkinan odd 2 kali meningkatkan kejadian JE. Jadi, tempat tinggal dekat dengan sawah merupakan faktor risiko. Pada kategori terdapat genangan air kotor disekitar rumah, sebanyak $28,57 \%$ yang terdapat disekitar rumah menderita sakit JE, dan sebanyak $11,8 \%$ tidak terdapat genangan air kotor dekat rumah menderita sakit JE.. Nilai odd ratio (OR) genangan air kotor dekat rumah adalah 2,4. Artinya, keadaan lingkungan dengan ada tidaknya genangan air kotor disekitar rumah terhadap kejadian JE kemungkinan odd 2,4 kali meningkatkan kejadian JE. Jadi, genangan air kotor disekitar rumah merupakan faktor risiko.

\section{DISKUSI}

Penyakit JE merupakan penyakit yang disebabkan oleh virus yang penyebarannya sangat berkaitan erat dengan kondisi lingkungan. Pada daerah persawahaan, terutama pada musim tanam yang selalu digenangi air dan hal ini diduga dapat berpengaruh terhadap endemisitas penyakit JE. sedangkan di daerah perkotaan, nyamuk ini dapat ditemukan dengan mudah di selokan dan air yang tergenang. Peningkatan transmisi penyakit ini juga dapat disebabkan karena peningkatan populasi nyamuk pada saat musim hujan (Depkes RI, 2007). Pada penelitian ini, kondisi lingkungan meliputi keberadaan sawah disekitar rumah dan keberadaan genagan air kotor di sekitar rumah.

Berdasarkan hasil analisis univariat yang telah dilakukan, diketahui bahwa sebesar $83,44 \%$ responden memiliki kondisi lingkungan yang berisiko. Banyaknya responden yang memiliki kondisi lingkungan yang berisiko tentunya akan dapat meningkatkan risiko tertular JE.

Hasil analisis bivariat antara kondisi lingkungan dengan kejadian JE menunjukkan bahwa $88,24 \%$ penderita JE tinggal dekat dengan sawah dan $78,36 \%$ non JE tinggal dekat dengan sawah. Ada perbedaan proporsi antara penderita JE dan non JE, dimana proporsi penderita JE yang tinggal dekat sawah lebih besar dibandingkan pada non JE. Hal ini tentunya akan meningkatkan risiko terkena penyakit JE bagi responden yang tinggal dekat dengan sawah.

Pada kategori genangan air disekitar rumah, diperoleh hasil 11,76\% penderita JE memiliki genangan air kotor disekitar rumah dan $5,22 \%$ non JE yang disekitar rumahnya terdapat genangan air kotor.

Penelitian ini sejalan dengan penelitian yang dilakukan di RSUP Sanglah tahun 2007. Hasil penelitian menunjukkan bahwa salah satu faktor yang berhubungan dengan JE yaitu tempat tinggal dekat sawah $(\mathrm{OR}=5,618)$ (Putra, dkk, 2007). Penelitian lain yang dilakukan di Nepal juga menunjukkan bahwa tingkat infeksi peternak sangat berhubungan dengan kedekatan dengan 
sawah dan genangan air (Ghimire, et al., 2014).

Adanya kondisi lingkungan yang berisiko ini akan menigkatkan penyebaran penyakit JE khususnya di Bali. Mengingat penelitian ini dilakukan di daerah dengan radius 100 meter dari kandang babi, dimana responden yang tinggal dekat dengan sawah dan genangan air kotor dapat meningkatkan faktor risiko JE. Oleh karena itu disarankan kepada pemerintah untuk selalu menggalakkan kampanye pencegahan JE melalui pendidikan kesehatan pada masyarakat dengan kondisi lingkunagan berisiko dan kepada masyarakat yang tinggal dekat sawah diharapkan setidaknya untuk tidak memelihara babi atau boleh memelihara babi tapi pada kondisi lingkungan yang buruk itu perlu dilakukan intervensi seperti memberikan larvasida pada daerah persawahan sehingga dapat menurunkan risiko terhadap JE. Karena populasi yang berada dalam radius 100 meter dari kandang babi atau memelihara babi, dan memiliki tempat tinggal dekat dengan sawah akan meningkatkan risiko terhadap JE.

\section{SIMPULAN}

Dengan demikian dapat disimpulkan bahwa kondisi lingkungan merupakan faktor risiko JE. kondisi lingkungan yang dimaksud meliputi keberadaan babi disekitar rumah, keberadaan sawah disekitar rumah, dan keberadaan genangan air kotor disekitar rumah. Oleh sebab itu disarankan kepada pemerintah untuk selalu menggalakkan kampanye pencegahan JE melalui pendidikan kesehatan pada masyarakat dengan kondisi lingkunagan berisiko.

\section{DAFTAR PUSTAKA}

Ardias, dkk. (2012). Faktor Lingkungan dan Perilaku Masyarakat yang Berhubungan dengan Kejadian Filariasis di Kabupaten Sambas. Jurnal Kesehatan Lingkungan Indonesia, 11 (2). Cao, M, et al. (2010). Contextual Risk Factors For Regional Distribution Of Japanese Encephalitis in The People's Republic of China. Tropical Medicine And International Health, 15 (8) : 918-923.

Departemen Kesehatan RI. (2007). Pedoman

Tatalaksana Kasus dan Pemeriksaan Laboratorium Japanese Encephalitis di Rumah Sakit. Direktorat Jenderal Pengendalian Penyakit dan Penyehatan Lingkungan, Jakarta.

Erlangger, TE,. Weiss S,. Keiser J. (2009). Past, Present, and Future Of Japanese Encephalitis. Emerging Infectious Disease, 15 (1) : 1-7.

Ghimire, S., et al. (2014). Pig Sero-Survey and Farm Level Risk Factors Assessment For Japanese Encephalitis In Nepal. Int J Appl Sci Biotecnol, 2(3) : 311-314.

Ompusunggu, S., Hills, SL., Maha, MS., Moniaga, VA., Susilarini, NK., Widjaja, A. (2008). Confirmation of Japanese Encephalitis as an Endemic Human Disease Through Sentinel Surveillance in Indonesia. Am J Trop Med Hyg, 79 (6) : 963-970.

Paramarta, IGE. \& Kari, SH. (2009). Faktor Risiko Lingkungan pada Pasien Japanese Encephalitis. Sari Pediatri, 10 (5). 
Putra, J. \& Kari, SH. (2007). Manifestasi Klinis dan Faktor-Faktor yang Berhubungan dengan Japanese Encephalitis Di RSUP Sanglah Denpasar. Sari Pediatri, 8 (3) : 15-20.

Sendow, I. \& Sjamsul, B. (2005). Perkembangan Japanese Encephallitis di Dindonesia. Wartazoa, 15 (3) : 111118. 